still. The chemical nature of the acceptors of GalNAc groups in the red cell membrane is under investigation.

H. SChENKEL-BRUNNER

H. TUPPY

Institut für Biochemie,

University of Vienna,

Wasagasse 9, A-1090 Wien, Austria.

Received June 27; revised August 7, 1969.

${ }^{1}$ Watkins, W. M., Science, 152, $172(1966)$.

${ }^{2}$ Hakomori, S., and Strycharz, G. D., Biochemistry, 7, 1279 (1968).

${ }^{3}$ Watkins, W. M., and Morgan, W. T. J., Vox Sang., 4, 97 (1959).

1 Tuppy, H., and Staudenbauer, W. L., Nature, 210, 316 (1966).

${ }^{5}$ Tuppy, H., and Schenkel-Brunner, H., Europ. J. Biochem., 10, 152 (1969).

- Hearn, V. M., Smith, Z. G., and Watkins, W. M., Biochem. J., 109, 315 (1968).

${ }^{7}$ Kobata, A., Grollman, E. F., and Ginsburg, V., Arch. Biochem. Biophys., 609 (1968).

${ }_{8}$ Tuppy, H., and Schenkel-Brunner, H., Vox Sang. (in the press).

${ }^{9}$ Race, C., Ziderman, D., and Watkins, W. M., Biochem. J., 10\%, 733 (1968).

${ }^{10}$ Kobata, A., Grollman, E. F., and Ginsburg, V., Biochem. Biophys. Res. Commun., 32, 272 (1968).

11 Bray, G. A., Anal. Biochem., 1, 279 (1960).

12 Economidou, J., Hughes-Jones, N. C., and Gardner, B., Vox Sang., 12 $321(1967)$.

\section{High Cell Wall Galactosamine Content and Virus Particles in Penicillium stoloniferum}

RECENTLY it has been shown ${ }^{1,2}$ that the active component of Statolon, an antiviral agent isolated from 5 day old culture filtrates of Penicillium stoloniferum (strain American Type Culture Collection-ATCC 14586), is double stranded RNA of viral origin, and not a complex poly. saccharide as originally suggested ${ }^{3}$. During this investigation it was discovered that Statolon contained three discrete polysaccharides, readily separable by high voltage paper electrophoresis: a heteroglycan, containing galact. uronic acid, galactose, xylose, arabinose and rhamnose; a glucan of the amylopectin-glycogen type (unpublished results of K. W. B., E. B. C. and J. M. Tyler) and a polymer of galactosamine, derived from lysis of the fungal cell wall. We now report that galactosamine is a major constituent of the cell wall of the virus-containing strain of $P$. stoloniferum (ATCC 14586); in contrast, cell walls of four naturally occurring virus-free* strains of $P$. stoloniferum (ATCC 10111, Commonwealth Mycological Institute 31200,91960 and 92219) and a virus-free* isolate (ATCC $14586 \mathrm{B3} / 1$ ) derived from the infected strain by heat treatment of spores ${ }^{1}$ containet only very small amounts of galactosamine. (It is possible that this heat treatment procedure resulted in selection of either a heat resistant or a mutant strain of ATCC 14586.)

Amino-sugars were liberated from cell walls, prepared from 2 day old mycelium, by hydrolysis with $5 \cdot 7 \mathrm{~N} \mathrm{HCl}$ at $100^{\circ} \mathrm{C}$ for $4 \mathrm{~h}$. Two amino-sugars (A and $\mathrm{B}$ ), which gave positive reactions with the ninhydrin ${ }^{4}$, silver nitrate ${ }^{5}$ and Elson-Morgan ${ }^{6}$ sprays, were detected by paper chromatography (ethyl acetate : pyridine : water : acetic acid 5:5:1:3, by vol. $)^{7}$. On oxidative deamination with ninhydrin ${ }^{8}$ they gave lyxose and arabinose, respectively, and were identified as galactosamine and glucosamine by paper chromatography and gas chromatography ${ }^{9}$ (Table 1). Talosamine and mannosamine, which also give lyxose and arabinose, respectively, on ninhydrin degrada. tion, are included for comparison.

Maximal yields of both hexosamines were obtained after $4 \mathrm{~h}$ hydrolysis. The amounts of anhydrohexosamine in the cell walls of the strains examined were determined by gas chromatography as described here (Table 2 ).

The cell walls of the virus-containing strain have between eighteen and forty-five times more galactosamine

* No virus particles could be detected in extracts from these strains by electron microscopy, sucrose density gradient centrifugation and serology but the possibility that particles were present below the level of detection
or that the virus was present in the "prophage" state cannot be excluded.
Table 1. IDENTIFICATION OF AMINO-SUGARS IN $P$. stoloniferum OELL WALLS

$\begin{array}{llcc}\text { Ninhydrin } & \begin{array}{c}\text { Paper } \\ \text { degradation } \\ \text { product }\end{array} & \begin{array}{c}\text { Gas chro- } \\ \text { graphic } \\ \text { mobility* }\end{array} & \begin{array}{c}\text { matographic } \\ \text { retention } \\ \text { time }\end{array} \\ \text { Amino-sugar A } & \text { Lyxose } & 1 \cdot 00 & 3 \cdot 36 \\ \text { Galactosamine } & \text { Lyxose } & 1 \cdot 00 & 3 \cdot 34 \\ \text { Talosamine } & \text { Lyxose } & 1 \cdot 30 & 2 \cdot 65 \\ \text { Amino-sugar B } & \text { Arabinose } & 1 \cdot 18 & 2 \cdot 87 \\ \text { Glucosamine } & \text { Arabinose } & 1 \cdot 18 & 2 \cdot 85 \\ \text { Mannosamine } & \text { Arabinose } & 1 \cdot 53 & 3.53\end{array}$

* Expressed as $R_{\text {galoctosamine values in ethyl acetate: pyridine: water }}$ $(5: 2: 5$, by vol.).

$\dagger$ Retention time of hexosaminitol hexa-acetate relative to sorbitol hexaacetate on a 5 foot column of 10 per cent neopentylglycol sebacate polyester on acid-washed 'Chromosorb $W^{\prime}$ ' at $240^{\circ} \mathrm{C}$, essentially as described by Perry and Webby.

Table 2. AMINO-SUGAR COMPOSITION OF $P$. stoloniferum CELL WALLS

$\begin{array}{lcccccc} & \text { ATCC } & \text { ATCC } & \text { ATCC } & \text { CMI } & \text { CMI } & \text { CMI } \\ \text { Culture } & 14586 & 14586 & 10111 & 31200 & 91960 & 92219\end{array}$

Per cent anhydro-

galactosamine

glucosamine

$\begin{array}{rrrrrr}18.1 & 0.7 & 0.6 & 0.7 & 1.0 & 0.4 \\ 16.6 & 13.7 & 23.0 & 22.9 & 22.6 & 16.4\end{array}$

than the virus-free strains; in contrast, the amounts of glucosamine do not vary widely. Galactosamine has been detected in the cell walls of a number of Ascomycetes ${ }^{10}$ and is a major component of the cell walls of the Trichomycete, Amoebidium parasiticum ${ }^{\mathrm{11}}$. Only small amounts of galactosamine were found, however, in the cell walls of $P$. notatum $(0 \cdot 9-1 \cdot 8 \text { per cent })^{12}$ and $P$. patulum $(0.5 \text { per cent })^{13}$, and none was reported in the cell walls of $P$. chrysogenum ${ }^{14}, P$. italicum ${ }^{15}$ and $P$. digitatum ${ }^{15}$. Our analyses of $P$. stoloniferum suggest that the large amount of galactosamine in the cell walls of strain ATCC 14586 may be associated with the presence of virus particles. Although such an effect has not been described previously in fungi, alterations of cell wall structure as a result of phage infection in bacteria have been widely reported ${ }^{26}$. The possibility that galactosamine forms part of a receptor site in the cell wall to which the virus binds in the initial stages of infection is being investigated. It has been suggested that galactosamine forms part of the phage receptor sites of group C Streptococcus ${ }^{17}$.

We thank Mr I. Blench for technical assistance, Miss V. J. Gross, who carried out certain preliminary experiments, and Dr M. B. Perry for a sample of 2-acetamido-2. deoxy-D-talitol.
K. W. BUCK
E. B. ChaIN
JoAN E. DARBYSHIRE

Biochemistry Department,

Imperial College of

Science and Technology,

London SW7.

Received August 1, 1969.

${ }^{1}$ Banks, G. T., Buck, K. W., Chain, E. B., Himmelweit, F., Marks, J. E. Tyler, J. M., Hollings, M., Last, F. T., and Stone, M. M., Nature, 218, 542 (1968).

${ }^{2}$ Kleinschmidt, W. J., Ellis, L. F., Van Frank, R. M., and Murphy, E. B., Natztre, 220, I 67 (i) 368 .

${ }^{3}$ Kleinschmidt, W. J., and Probst, G. W., Antibiot. Chemother., 12, 298 (1962).

- Aminoff, D., and Morgan, W. T. J., Nature, 162, 579 (1948).

${ }^{6}$ Trevelyan, W. E., Procter, D. P., and Harrison, J. S., Nature, 155, 444 (1950).

' Smith, I., Chromatographic and Electrophoretic Techniques, 1, 252 (Heinemann, London, 1960).

7 Fischer, F. G., and Nebel, H. J., Z. Physiol. Chem., 302, 10 (1955).

s Stoffyn, P. J., and Jeanloz, R. W., Arch. Biochem. Biophys., 52, 373 (1954).

- Perry, M. B., and Webb, A. C., Canad. J. Riochem., 46, 1163 (1968).

${ }^{10}$ Bartnicki-Garcia, S., Ann. Rev. Microbiol., 22, 97 (1968).

11 Trotter, M, J., and Whistler, H. C., Canad. J. Bot., 43, 869 (1965).

12 Applegarth, D. A., Arch. Biophys. Biochem., 120, 471 (1967).

${ }^{13}$ Applegarth, D. A., and Bozoian, G., J. Bact., 94, 1787 (1967).

14 Hamilton, R. B., and Knight, S. G., Arch. Biochem. Biophys., 99, 282 (1962).

${ }^{15}$ Grisaro, V., Sharon, N., and Barkai-Golan, R., J. Gen. Microbiol., 51, 145 (1968).

${ }^{18}$ Lüderitz, O., Jann, K., and Wheat, R., in Comprehensive Biochemistry (edit. by Florkin, M., and Stotz, F. H.), 26A, 106 (Elsevier, Amsterdam, 1968).

12 McCarty, M., and Morse, S. I., Adv. Immunology, 6, 249 (1964). 